JKKP : Jurnal Kesejahteraan Keluarga dan Pendidikan

http://doi.org/10.21009/JKKP

DOI: doi.org/10.21009/JKKP.042.08

E-ISSN : 2597-4521

\title{
Perancangan Program Day Care Berbasis Experiential Learning di Prodi Pendidikan Kesejahteraan Keluarga
}

\author{
Nur Mu'jizatin ${ }^{1 . a)}$, Yoyoh J ubaedah ${ }^{2 . b)}$, Isma Widiaty ${ }^{3, c)}$ \\ Email : a)nur.mujizatin@student.upi.edu \\ 1,2,3)P rogram Studi Pendidikan Kesejahteraan Keluarga FPTK \\ Universitas Pendidikan Indonesia
}

\begin{abstract}
Abstrak
Penelitian ini dilatarbelakangi belum adanya program day care berbasis experiential learning di laboratoruim Prodi PKK. Penelitian ini bertujuan untuk menganalisis kebutuhan perancangan program di day care, merancang program day care berbasis experiential learning, melaksanakan expert judgmant, dan menghasilkan program day care berbasis experiential learning. Penelitian ini menggunakan pendekatan ADDIE yang telah dimodifikasi oleh peneliti sesuai dengan kebutuhan, sehingga peneliti hanya melakukan empat tahapan yaitu meliputi Analysis, Design, Development, dan Evaluation. Sampel penelitian ini terdiri dari penggelola day care dan Ibu bekerja yang memiliki anak usia balita. Program day care yang dirancang terdiri dari profil lembaga,tujuan, komponen penyelenggaraan day care, interaksi dan komunikasi, proses pelaporan, dan pembelajaran berbasis experiential learning. Hasil expert judgmant mengenai program day care berbasis experiential learning berada pada kategori sangat layak. Ketercapaian kriteria tersebut tervalidasi oleh para ahli dan praktisi yang terdiri dari aspek profil lembaga,tujuan, komponen penyelenggaraan day care, interaksi dan komunikasi, proses pelaporan, dan pembelajaran berbasis experiential learning. Rekomendasi untuk pengelola day care agar dapat memfailitasi sarana dan prasarana untuk keberlangsungan program day care. Saran bagi orangtua untuk lebih selektif dalam memilih tempat day care. Bagi peneliti selanjutnya program day care dapat diuji coba dan diimplementasikan, dengan menyesuaikan karakteristik anak usia dini, sarana dan prasarana yang ada di day care. Program pembelajaran berbasis experiential learning dapat diterapkan di lembaga PAUD seperti Taman Kanak-Kanak, Kelompok Bermain, Tempat Penitipan Anak dan Sekolah PAUD Sejenis sebagai program pembelajaran untuk anak usia dini.
\end{abstract}

Kata kunci: program day care, experiential learning, anak usia dini

\section{Design Of Daycare Program Based On Experiental Learing In Family Welfare Education Study Program}

\begin{abstract}
this research is back to the absence of an experiental learning based day care program in the laboratory of PKK study program. purpose of this research is analyzing needs of program design at daycare, designing daycare program based on experiental learning, arry out expert judgment, and produce daycare program based on experiental learning. this research using ADDIE aproach that have been modified by researcher as needed, so researcher just need to do four steps like, analysis, design, development and evaluation. sample of this research are day care manager and workmother who has toddlers. day care program designed institutional profile, purpose, daycare component, interaction and comunication, report process, and learning based on experiental learning. result of expert judgment about is feasible. the recomendation for daycare manager is for facilitated facilitation
\end{abstract}


and infastructure at daycare. for parents could more selective for choosing daycare. for next researcher can test the program and implement according to the characteristic of child. program can be applied in PAUD like, kindergarten, playgroup and daycare.

Key words: day care program, experiential learning and toddlers

\section{PENDAHULUAN}

Keluarga adalah lembaga yang fundamental. Keluarga memiliki peranan penting dalam membimbing dan mengembangkan tumbuh kembang bagi anak-anaknya, kerena keluarga memiliki peranan penting dalam melahirkan generasi yang baik dan jujur, memberikan manfaat kebaikan di dalam agama, serta memberikan konstribusi yang baik bagi negara dan bangsa. "Keluarga adalah wahana yang utama dan pertama bagi anggota-anggotanya untuk mengembangkan potensi, mengembangan aspek sosial, dan ekonomi, serta menyemain kasih sayang antara anggota keluarga" (Puspitawati dan Sarman, 2012, hlm. 22).

Keadaan keluarga terkadang tidak sejalan lurus dengan yang diinginkan, salah satu contohnya yaitu pola hidup keluarga dan masyarakat kita yang telah berubah. Perempuan yang identiknya berperan sebagai ibu rumah tangga kini telah memiliki peran ganda yaitu berperan sebagai ibu berkarir. Peran ganda seperti ini menjadikan konflik tersendiri bagi ibu yang tidak mampu mengatasinya.

Berbagai faktor menjadi alasan seorang ibu untuk bekerja atau berkarir, mulai dari faktor ekonomi, sosial, tingkat pendidikan, dan faktor yang lainnya. Perempuan yang merangkap sebagai ibu rumah tangga sekaligus ibu yang bekerja bukan hal yang asing lagi bagi kita. Keseriusan seorang perempuan yang berstatus sebagai ibu dalam meniti karirnya kini telah banyak kita jumpai, mulai dari sektor pendidikan, industri, kesehatan, publik dan lain sebagainya. Permasalahan seperti ini akan mempengaruhi peranannya dalam keluarga terutama dalam pengasuhan anak-anaknya.

Mengatasi permasalahan yang dialami oleh seorang ibu yang berkarir, maka diperlukan suatu bantuan lembaga yang mampu menjadi penganti dari peran seorang ibu. "Dalam mengatasi segala permasalahan beban ganda perempuan baik di sektor domestik maupun publik ini, maka diperlukan suatu lembaga yang memiliki fungsi layanan sosial sebagai pengasuh anak ketika perempuan sedang bekerja, lembaga ini merupakan bagian dari pendidikan anak usia dini (TPA)" (Hidayah, 2008, hlm. 24).

Day care atau Tempat Penitipan Anak merupakan salah satu alternatif yang sekarang banyak ditawarkan oleh lembaga untuk orangtua yang memiliki kesibukan di luar rumah, tanpa harus menghawatirkan akan kualitas pelayanan dan pendidikan bagi seorang anak. "Day care atau Taman Penitipan Anak merupakan salah satu bentuk satuan PAUD jalur pendidikan nonformal yang menyelenggarakan program pendidikan bagi anak sejak lahir sampai dengan usia 6 (enam) tahun dengan prioritas sejak lahir sampai usia 4 tahun" (Direktorat Pembinaan Pendidikan Anak Usia Dini, 2015, hlm. 4).

Seorang ibu yang bekerja dan memiliki waktu yang terbatas, sebuah tempat penitipan anak atau day care sudah menjadi kebutuhan yang kursial, "day care diciptakan untuk memenuhi kebutuhan orangtua yang memiliki kesibukan dan memiliki waktu yang terbatas untuk mengurus anaknya" (Seotrisno, 2013).

Survei yang dilakukan kepada dosen FPTK UPI pada tahun 2016, mendapatkan data bahwa terdapat 12 dosen FPTK yang memiliki anak usia balita, sehingga tidak menutup kemungkinan jumlah dosen yang memiliki anak usia balita di fakultas yang lain juga memilih jumlah anak usia balita yang tidak jauh berbeda dengan dosen dari FPTK. Data dosen FPTK yang memiliki anak usia balita akan disajikan dalam bentul tabel 1.1 dibawah ini: 
Tabel 1.1 Data Dosen yang Memiliki Anak Usia Balita

\begin{tabular}{lll}
\hline No & \multicolumn{1}{c}{ Dosen } & J umlah \\
\hline 1 & Pendidikan Agro Industri & 1 orang \\
2 & Pendidikan Arsitektur & 5 orang \\
3 & Pendidikan Kesejahteraan & 3 orang \\
& Keluarga & \\
4 & Pendidikan Elektro & 1 orang \\
5 & Pendidikan Sipil & 2 orang \\
6 & Pendidikan Mesin & - \\
& Jumlah & 12 \\
\hline
\end{tabular}

Pemilihan tempat day care yang berkualitas juga perlu diperhatikan oleh seorang ibu, yaitu day care yang mampu menyediakan program yang berpusat pada aktivitas anak. Day care bagi anak bukan sekedar tempat untuk bermain atau belajar yang berorientasi pada segi akademis saja, seperti membaca, menulis, menggambar, dan berhitung, melainkan menitik beratkan ke arah pertumbuhan dan perkembangan anak, mulai dari pertumbuhan dan perkembangan nilai-nilai agama dan moral, fisik-motorik, kognitif, bahasa, sosial-emosional dan seni, dengan demikian pelayanan day care harus dapat mengakomodasi semua aspek perkembangan anak dalam suasana yang menyenangkan dan menarik minat anak untuk beraktivitas.

Pemilihan tempat day care yang tepat akan memberikan hasil pertumbuhan dan perkembangan yang optimal bagi anak. Menitipkan anak di day care tidak selamanya berdampak negatif bagi anak, atau sebaliknya selalu berdampak positif bagi anak. "Yang menentukan baik tidaknya dampak menitipkan anak di daycare adalah kualitas dari daycare itu sendiri, sedangkan hal yang paling menentukan kualitas day care adalah kualitas para pengasuh di daycare tersebut" (Abahdehya, 2015).

Laboratorium day care di Prodi PKK FPTK UPI telah memiliki tempat day care dengan fasilitas seperti ruang bermain, ruang makan, ruang istirahat, ruang belajar, perpustakaan dan fasilitas yang lainnya. Penyelenggaraan day care ini merupakan salah satu bentuk perhatian dari Prodi PKK guna memenuhi kebutuhan layanan masyarakat yang berada di lingkungan FPTK UPI yang membutuhkan fasilitas tempat penitipan anak.

Day care di laboratorium prodi PKK beberapa tahun kebelakang sudah tidak berjalan, dipersepsi oleh peneliti bahwa kemungkinan kurangnya sumber daya manusia dan manajemen yang ada di laboratorium prodi PKK, sedangkan sumber daya manusia dan manajemen adalah salah satu faktor penting dalam berlangsungnya penyelenggeraan day care mulai dari penggasuh, pengelola, pegawai dan lain-lain. "Sumber daya manusia merupakan faktor yang paling mempengaruhi kehidupan, posisi sumber daya manusia sentral adanya" (Arifah, dkk., 2015, hlm 296).

"Seiring dengan tuntutan kompetisi global, khususnya dalam mengelola sumber daya manusia, tren dewasa ini menunjukkan bahwa kinerja organisasi dapat optimal apabila anggota organisasi tersebut memiliki kompetensi yang handal di bidangnya" (Fatimah, 2016, hlm. 122). Menjabarkan pendapat di atas bahwa pengelolaan sumber daya manusia di day care dapat dibentuk oleh kemampuan lembaga dalam memanajemen anggotanya mulai dari pengelolaan pencapaian tujuan di day care, pemecahan masalah, interaksi antara anak dan pengasuh, dan cara kerja tim yang ada di day care, dimana peranan kompetensi sumber daya manusia akan sangat menentukan kemajuan lembaga (day care) dalam menghadapi berbagai perubahan dan tuntutan yang ada.

Kegiatan day care perlu dirancang sedemikian rupa untuk membantu anak mendapatkan simulasi kehidupan yang nyata dalam kegiatan sehari-hari. Kegiatan-kegiatan di day care akan disesuikan dengan tahap pertumbuhan dan perkembangan dengan memperhatikan prinsip-prinsip dari model pembelajaran experiantial learning. "Muatan experiantial learning pada kegiatan outbound dinilai efektif dalam mengembangkan potensi anak usia dini" (Susari, 2009, hlm. 123). Model pembelajaran experiential learning merupakan salah satu elemen pembelajaran sebagai sasaran perbaikan yang mendesak untuk dilakukan, sehingga peneliti tertarik untuk mengimplementasikan model pembelajaran experiential learning ini di day care prodi PKK.

Berdasarkan pertimbangan dari fenomena dan peluang untuk day care di laboratorium prodi PKK tersebut, peneliti tertarik mengangkat masalah day care untuk diteliti dan mengembangkan program day care berbasis experiential learning yang ada di laboratorium Prodi PKK. Uraian permasalahan di atas mengenai perancangan day care berbasis experiential learning erat kaitanya 
dengan ilmu yang dipelajari peneliti pada mata kuliah manajemen pelayanan anak dan lansia. Berangkat dari latar belakang masalah tersebut, peneliti termotivasi untuk merancang program day care berbasis experiential learning di Prodi Pendidikan Kesejahteraan Keluarga.

\section{METODOLOGI PENELITIAN}

Metode yang digunakan dalam penelitian ini adalah metode deskriptif dengan model ADDIE. Pendekatan ADDIE telah dimodifikasi oleh peneliti sesuai dengan kebutuhan, sehingga peneliti hanya melakukan tiga tahapan yang meliputi Analysis, Design, dan Development. berikut:

Tahapan penelitian yang akan dilakukan dengan menggunakan Model Addie, adalah sebagai

1. Analisis, Tahap analisis dalam penelitian ini adalah kegiatan menganalisis kebutuhan perancangan program di day care sesuai dengan kebutuhan orangtua yang berada di sekitar lingkungan FPTK. Analisis dilakukan untuk mengetahui tujuan dan sasaran dirancangnya program day care berbasis experiential learning di Prodi PKK FPTK UPI.

2. Desain. Tahap desain dalam penelitian ini adalah perancangan program day care berbasis experiential learning berdasarkan dari hasil analisis, dalam tahap desain ini akan dilakukan perancangan untuk kegiatan dan kebutuhan yang lainnya.

3. Pengembangan. Tahap pengembangan dalam penelitian ini adalah pengembangan program day care berbasis experiential learning sesuai dengan kebutuhan lbuu yang bekerja disekitaran lingkungan FPTK UPI. Setelah program dirancang, maka akan dilakukan validasi desain program day care berbasis exjjperiential learning menggunakan expert judgment oleh beberapa pakar atau tenaga ahli yang sudah berpengalaman untuk menilai program yang telah dirancang, sehingga selanjutnya dapat diketahui kelebihan dan kelemahan program. Oleh karena itu pada tahap ini, jika program yang telah divalidasi dapat diketahui kelemahannya, maka akan dilakukan perbaikan desain sesuai arahan dari validator.

Sumber data dalam penelitian ini diperoleh dari ketua Laboratorium Day care PKK, pengelola day care yang sudah profesional, responden (ibu bekerja) yang memiliki anak usia balita yang berada di lingkungan FPTK UPI, ahli manajemen pengelolaan pendidikan, ahli pendidikan anak dan praktisi.

Lokasi penelitian bertempat di laboratorium Day care Prodi PKK FPTK UPI di Jln. Setia Budhi. Instrumen penelitian yang digunakan adalah pedoman wawancara, observasi, dan format validasi expert judgment. Wawancara dilakukan kepada pengelola laboratorium day care dan pengelola day care yang ada di lingkungan UPI. Observasi digunakan untuk melakukan tindak lanjut dari metode wawancara yang bertujuan untuk menggali data mengenai variabel yang sudah ditentukan yang berkaitan dengan kebutuhan analisis. Format expert jugment digunakan untuk mengetahui kelayakan program yang dibuat peneliti untuk ditunjukkan kepada validator.

Analisis data yang dilakukan dalam penelitian ini meliputi: reduksi data untuk merangkung hasil wawancara dan observasi, display data untuk menggambarkan data secara umum dari hasil penelitian, validasi data menggunakan expert judgment, dan revisi untuk memperbaiki hasil perancangan program.

\section{HASIL PENELITIAN DAN PEMBAHASAN}

\section{Temuan Penelitian}

a. Data analisis kebutuhan perancangan program didapat melalaui awancara kepada ketua laboratorium day care Prodi PKK, pengelola day care yang berada di sekitar UPI, dan orangtua yang memiliki anak usia balita di lingkungan FPTK UPI.

b. Desain perancangan program day care berbasis experiential learning dilakukan setelah menganalisis kebutuhan perancangan program yang telah dilakukan melalui wawancara kepada pengelola day care dan orangtua sebagai konsumen yang berada di lingkungan kampus UPI.

c. Hasil expert judgment yang telah dilakukan oleh akademisi dan praktisi dibidang ahli pendidikan anak usia dini dan ahli manajemen pendidikan meliputi komponen perancnagan program day care berbasis experiential learning, yaitu: profil lembaga, tujuan, komponen penyelenggaraan, interaksi dan komunikasi, dan proses pelaporan. Penyelenggaraan program secara keseluruhan sudah sesuai, namun masih diperlukan pengembangan. 
d. Pengembangan perancangan program day care berbasis experiential learning dilakukan setelah mendapatkan hasil expert judgment dari akademisi dan praktisi day care. Saran dan komentar yang diberikan yang diberikan oleh akademisi dan praktisi day care dijadikan rujukan untuk pengembangan rancangan program.

e. Program day care berbasis experiential learning yang telah direvisi dan dikembangkan belum diuji cobakan karena belum adanya anak asuh di day care laboratorium Prodi PKK. Hasil dari perancangan program day care ini adalah buku panduan penyelenggaraan day care yang meliputi:

1) Profil lembaga day care meliputi: visi dan misi, tujuan day care, struktur Organisasi, tata lokasi/denah, daya tampung, sasaran, dan waktu.

2) Komponen penyelenggraan terdiri dari pendidik, pengasuh, sarana dan prasarana, serta deteksi tumbuh kembang anak.

3) Pembelajaran berbasis experiential learning meliputi: muatan pembeajaran, perencanaan pembelajaran, metodologi pembelajaran, dan jadwal kegiatan anak.

4) Proses pelaporan akan diberikan kepada dua pihak yaitu: dinas pendidikan yang meliputi; ketenagaan peserta didik, dan sarana prasarana yang ada di day care, dan pelaporan akan diberikan kepada orangtua peserta didik melalui buku dan media penghubung.

Di bawah ini akan digambarkan model dari perancangan program yang telah dibuat oleh peneliti. Model desain adalah gambaran model tentang day care berbasis experiental learning. Model day care ini meliputi pendekatan sistem, kegiatan dan fasilitas kegiatan day care. Ketiga model ini akan digambarkan dalam bagan dibawah ini.

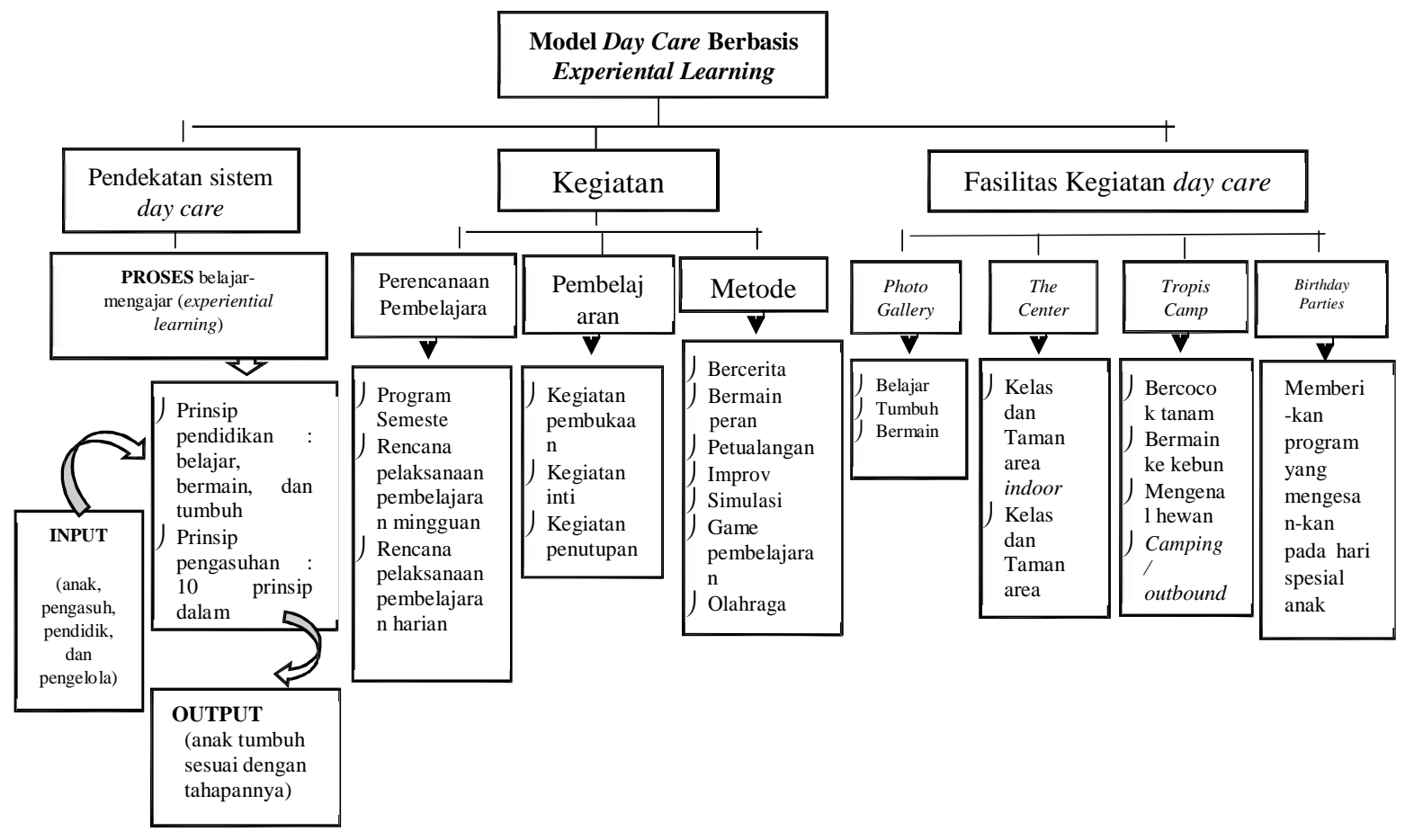

Gambar 2. Model day care berbasis experiental learning

\section{Pembahasan Penelitian}

Profil sangat diperlukan dalam sebuah lembaga, profil merupakan salah satu ciri khas untuk mengetahui keberadaan suatu lembaga, dan dengan adanya profil pada suatu lembaga akan lebih mudah dikenal oleh masyarakat. Rumusan profil lembaga day care berbasis experiential learning yang peneliti rancang mengacu pada pendapat Nirwani (2014) yang menggambarkan bahwa dalam merancang sebuah program day care diperlukan sebuah profil lembaga day care, diantaranya 
adalah nama day care, visi dan misi, struktur organisasi, alamat (lokasi), bentuk kegitan, sasaran, dan waktu pelayanan.

Komponen penyelenggaraan day care tediri dari pengasuh, pendidik, tenaga kependidikan, sarana prasarana, kegiatan pembelajara, dan deteksi tubuh kembang anak. Komponen ini akan dipaparkan sebagai berikut:

Kriteria pengasuh yang telah dirancang oleh peneliti memiliki sembilan kriteria yaitu memiliki ijazah Sarjana (S1) PG-PAUD atau sejenis; menguasai karakteristik peserta didik dari aspek fisik, moral-emosional, dan intelektual; menyelenggarakan kegiatan pengembangan yang mendidik; memfasilitasi pengembangan potensi peserta didik untuk mengaktualisasikan berbagai potensi anak; berperilaku jujur, berkakhlak mulia, dan teladan bagi anak dan masyarakat; memahami tahap perkembangan anak; memanfaatkan teknologi informasi dan komunikasi untuk berkomunikasi dan pengembangan diri; berkomunikasi secara efektif, empatik, dan santun terhadap anak; bersikap inklusif, bertindak objektif, dan tidak diskriminatif dalam pengasuhan dan perawatan kepada anak.

Peneliti merumuskan sebelas kriteria bagi pengasuh yaitu: telah mengikuti pelatihan dalam pengasuhan anak; memahami cara mengasuh anak yang tepat sesuai dengan tahap perkembangan; telaten dan teliti dalam memenuhi kebutuhan anak, berpenampilan rapi, bersih dan sehat; memiliki sikap, tutur kata dan bahasa yang baik, dan penuh kasih sayang kepada anak; memiliki motivasi untuk terus belajar tentang cara pengasuhan anak; menguasai karakteristik anak dari aspek fisik, moral-emosional, spiritual, dan intelektual; memanfaatkan teknologi informasi dan komunikasi untuk berkomunikasi dan pengembangan diri; berkomunikasi secara afektif, empatik, dan santun terhadap anak; bersikap inklusif, bertindak objektif, dan tidak diskriminatif dalam pengasuhan dan perawatan kepada anak; terampil bermain dan berkomunikasi secara verbal dan non verbal dengan anak dan staf yang lainnya; memahami agama; terbebas dari penyakit.

Kriteria pengasuh dan pendidik tersebut dirumuskan dengan merujuk pada Permendikbud nomor 137 tahun (2014) yang meliputi:

a. Memiliki kompetensi pedagogik

b. Memiliki kompetensi kepribadian

c. Memiliki kompetensi profesional

d. Memiliki kompetensi sosial

Sarana dan prasarana yang dirancang sesuai dengan kebutuhan anak untuk memberikan layanan pengasuhan dan pembelajaran selama anak berada di day care. Sarana dan prasarana di dalam peyelenggaraan day care terdiri dari lingkungan belajar, prasarana belajar, sarana penunjang, dan alat permainan edukatif (APE). Sarana dan prasarana yang disusun oleh peneliti memperhatikan pada prinsip-prinsip yang dipaparkan oleh Mulyana (2012, hlm. 259-260) yang meliputi:

a. Aman, nyaman, terang, dan memenuhi kriteria kesehatan anak

b. Sesuai dengan tingkat perkembangan anak

c. Memanfaatkan potensi dan sumber daya yang ada di lingkungan sekitar, termasuk limbah/bekas layak pakai.

Sarana dan prasarana yang dirancang dapat membantu dalam memberikan pelayanan yang baik pada anak di day care. Sarana dan prasarana yang baik dan beragam dapat membatu perkembangan anak secara optimal. Hal ini sesuai dengan pendapat Hastuti (2009) bahwa sarana yang beragam dan lengkap akan meningkatkan perkembangan motorik dengan lebih baik dibandingkan dengan sarana yang kurang beragam.

Perancanaan pembelajaran yang dirancang dapat dijadikan acuan oleh para pengasuh dan pendidik dalam melaksanakan kegiatan pengasuhan, perawatan, bimbingan dan pendidikan selama anak di day care. Pembelajaran dan pengasuhan di day care tanpa perencanaan akan berdampak kurang efektif pada aktivitas pelaksanaannya. Pentingnya perencanaan pembelajaran di day care ini sejalan dengan pendapat Edi (2011) yang menjelaskan bahwa perencanaan pembelajaran adalah untuk membantu guru dalam memikirkan pelajaran secara mendalam untuk memecahkan masalah dan kesulitan-kesulitan, memberikan struktur pembelajaran, dan memberikan rekaman tentang apa yang telah diajarkan. Perancangan pembelajaran juga perlu memperhatikan prinsip-prinsip pembelajaran.

Hal ini sesuai dengan pendapat Desiyanti, dkk (2015, hlm. 5) yang menyatakan bahwa ada empat komponen yang harus diperhatikan dalam penyelenggaraan tempat penitipan anak (TPA) yaitu:

a. Proses pembelajaran didasarkan pada prinsip-prinsip perkembangan anak

b. Pembelajaran anak usia dini dilaksanakan berdasarkan prinsip belajar melalui bermain

c. Proses pembelajaran anak usia dini dilaksanakan dalam lingkungan yang bersih, aman, nyaman, dan inovatif 
d. Pembelajaran anak usia dini harus dilaksanakan dengan pendekatan tematik dan terpadu.

Metode yang digunakan dalam pembelajaran berbasis experiential learning berupa metode bercerita, bermain peran, petualangan, improvisasi, simulasi, game pembelajaran, dan olahraga. Metodologi pembelajaran tersebut sejalan dengan pendapat Silberman (2014, hlm 101-102) yang mengemukakan bahwa metodologi yang dapat digunakan dalam pembelajaran berbasis experiential learning terdiri dari simulasi experiensial, pembelajaran tindakan, olahraga dengan barang bekas, game pembelajaran, simulasi berbasis komputer, improvisasi, pembelajaran petualangan, permainan peran, bercerita, dan praktik reflektif.

Deteksi tumbuh kembang anak sangat diperlukan dalam penyelenggaraan day care, hal ini karena anak pada usia dini memiliki pertumbuhan dan perkembangan yang sangat pesat sehingga pengasuh dan pengelola day care perlu melakukan pemeriksaan sejak dini dan teratur untuk menghindari hal-hal yang tidak diinginkan. Pentingnya deteksi tumbuh kembang pada anak yang telah peneliti rancang mengacu pada pendapat Palasari \& Purnomo (2012, hlm. 13) yang menyatakan bahwa kurangnya keterampilan orangtua (pengasuh) tentang deteksi tumbuh kembang anak dapat mengakibatkan gangguan tumbuh kembang yang berupa penyimpangan pertumbuhan, penyimpangan perkembangan, serta mental emosional.

Berdasarkan pendapat tersebut, maka deteksi tumbuh kembang anak pada program day care berbasis experiential learning yang dirancang oleh peneliti terdiri dari deteksi pertumbuhan dan deteksi perkembangan. Deteksi perkembangan memiliki bentuk kegiatan yang meliputi menimbang berat badan, mengukur tinggi/panjang anak, mengukur lingkar kepala, dan memeriksa bagian kepala. Perkembangan anak meliputi sosial-emosional, kemandirian, bahasa, fisik-motorik, dan kognitif.

Perumuskan pelaporan kegiatan diberikan untuk menjelaskan hasil penilaian pengasuh dan pendidik terhadap pertumbuhan dan perkembangan anak. "Tujuan pelaporan adalah untuk memberikan penjelasan kepada orangtua dan pihak lain yang memerlukan informasi tentang pertumbuhan dan perkembangan serta hasil yang dicapai oleh anak selama berada pada PAUD" (Mulyasa, 2012, hlm. 209). Penjelasan tersebut juga diperkuat dengan panduan pelaporan pada Peraturan Pemerintah dalam Standar Pendidikan Anak Usia Dini nomor 58 (2009) bahwa laporan perkembangan anak disampaikan kepada orangtua dalam bentuk pelaporan lisan dan tertulis secara bijak, disertai saran-saran yang dapat dilakukan oleh orangtua di rumah. Berdasarkan acuan tersebut, pelaporan yang dipilih dalam program day care berbasis experiential learning ini terdiri dari dua macam, yaitu:

1) The Connection Parents Book (raport/BUKOM)

2) The Connection Parents Media (media whatsapps atau line).

\section{SIMPULAN}

Simpulan pada bab ini dibuat dengan memperhatikan tujuan penelitian, hasil pengelolaan data penelitian dan pembahasan penelitian. Adapun simpulan pada penelitian ini yaitu:

a. Analisis kebutuhan perancangan program day care berbasis experiential learning bagi day care laboratorium Prodi PKK, menyatakan bahwa:

1) Lembaga day care membutuhkan profil lembaga yang lengkap untuk mengetahui keberadaan lembaga, ciri khas lembaga, dan dapat dikenal oleh masyarakat dengan mudah.

2) Tujuan lembaga menjadi acuan bagi pengelola, pengasuh, dan orangtua untuk memberikan pelayanan dan pendidikan yang terbaik bagi anak-anak di day care.

3) Perlu adanya pedoman untuk pengasuhan dan pembelajaran bagi anak, dengan memperhatikan aspek-aspek kognitif, fisik-motorik, sosial-emosional, agama, bahasa, dan seni.

4) Kebutuhan penyelenggaraan day care terdiri dari pengasuh, pendidik, sumber daya manusia/tenaga kependidikan, sarana dan prasarana, serta hubungan yang baik antara pihak pengelola day care dengan orangtua anak.

b. Program day care berbasis experiential learning terdiri dari profil lembaga, tujuan, komponen penyelenggaraan day care, interaksi dan komunikasi, serta proses pelaporan perkembangan anak di day care.

c. Hasil expert judgment mengenai program day care berbasis experiential learning pada pelayanan pengasuhan dan perawatan berada pada kriteria sangat layak. Kriteria tersebut divalidasi oleh para ahli yang terdiri dari aspek profil lembaga, tujuan, komponen penyelenggaraan day care, interaksi dan komunikasi, serta proses pelaporan. 
d. Hasil program day care berbasis experiential learning terdiri dari aspek profil lembaga, tujuan, komponen penyelenggaraan day care, interaksi dan komunikasi, serta proses pelaporan.

\section{Rekomendasi}

Hasil penelitian yang telah dilakukan oleh peneliti dapat dikemukakan beberapa saran yang dapat dijadikan masukan dan pertimbangan bagi berbagai pihak terkait yang berhubungan dengan rancangan program day care berbasis experiential learning, yaitu:

1. Bagi Pengelola Day Care

Program day care berbasis experiential learning dapat diimplementasikan di day care Prodi PKK dan day care yang lainnya dengan memfasilitasi sarana dan prasarana yang dapat menunjang kebutuhan anak untuk terlaksananya pengasuhan dan pembelajaran berbasis experiential learning.

2. Bagi Konsumen (Orangtua)

Pelayanan program day care merupakan salah satu alternatif bagi lbu yang memiliki peran ganda. Banyaknya program day care yang ada, orangtua perlu selektif dalam memilih program yang terbaik yang ditawarkan di day care.

3. Bagi Peneliti Selanjutnya

a. Program day care belum diimplemntasikan di lapangan secara langsung. Peneliti selanjutnya dapat melakukan uji coba di day care laboratorium Prodi PKK ataupun di day care yang lain dengan menyesuaikan karakteristik anak usia dini, sarana dan prasarana yang ada di day care.

b. Program pembelajaran berbasis experiential learning dapat diterapkan di day care atau di lembaga PAUD seperti Taman Kanak-Kanak (TK), Kelompok Bermain (KB), dan Sekolah PAUD Sejenis (SPS) sebagai program pembelajaran untuk anak usia dini.

\section{DAFTAR PUSTAKA}

Abahdehya. 2015. Menitipkan Anak di Day Care Positif atau Negatif. Di akses dari http://www.homydaycare.com/menitipkan-anak-di-daycare-positif-atau-negatif.

Arifah, dkk. 2015. Pengembangan Sumber Daya Manusia Di Lembaga Organisasi Pelayanan Sosial (Studi Kasus Mengenai Pelatihan Karyawan Di Aksi Cepat Tanggap J akarta Selatan). 3 (3), hlm. 292-428.

Edi, R. 2011. Perencanaan Pembelajaran. Di akses dari http://skp.unair.ac.id/repository/Guru_Indonesia/perencanaanpembelajaran_RelitNurEdi_1458 5.pdf.

Fatimah, S. 2016. Analisis Manajemen Sumber Daya Insani Berbasis Kompetensi Di Panti Asuhan Dan Pondok Pesantren Arrodiyah Semarang. Di akses dari http://ejournal.uinsuka.ac.id/dakwah/JMD/article/view/999. Pdf.

Hastuti, D. 2009. Simulasi Psikososisal Pada Anak Kelompok Bermain dan Pengaruh pada Perkembangan Motorik, Kognitif, Sosial E mosional, dan Moral/Karakter Anak. 2(1), hlm. 41-56.

Hidayah, N. 2008. Layanan Pada Anak Usia Dini (Studi Kasus Di TPA Beringharjo Yogyakarta). 2 (1), hlm. 23-49.

Mulyana. 2012. Manajemen PAUD. Bandung: Rosda.

Nirwani, S. 2014. Proposal Penawaran Kerja Sama Usaha. Di akses dari http://tempatpenitipananak.com/wp-content/uploads/2014/11/penawaran-kemitraan-tpapaudsanaya.pdf.

Peraturan Menteri Pendidikan dan Kebudayaan. 2014. Satandar Nasional Pendidikan Anak Usia Dini. Jakarta: Depdikbud.

Puspitawati \& Sarma. 2012. Sinergisme Keluarga dan Sekolah. Bogor: IPB Pres.

Silberman, M. 2014. Experiential Learning Strategi Pembelajaran dari Dunia Nyata. Bandung: Nusamedia. 